\title{
KRIITIK PEETER PILSKI ELULOOME STRATEEGIAD
}

\author{
AURIKA MEIMRE
}

\section{Eluloome kui selline}

$\mathrm{E}$ luloome (vn жизнетворчество, sks Lebenskunst, ingl life-creation ${ }^{1}$ ) kui teatav fenomen on XX sajandi alguse vene hõbeajastu (vn серебряный век), aga ka sajandi jagu varasema kuldajastu, romantismi esindajate, lahutamatu ja loominguliselt oluline osa. ${ }^{2}$ Kõige üldisemalt võiks eluloome tähendada oma elu, eluloo (biograafia) kujundamist vastavalt inimese väärtushinnangutele, mis on kooskõlas tema ajastu väärtustega. Erinevalt tavainimesest kujundasid mitmed XX sajandi alguse vene kultuuritegelased oma elukäiku teadlikult, n-ö mütologiseerisid selle. Vene noorema põlvkonna sümbolist, modernist Andrei Belõi kirjutas 1908. aastal artiklis „Sümbolism”, et kunstnik peab samastuma tema loodud vormiga, tema „loomuomane mina peab ühtima loominguga, tema elust peab saama looming" (Belõi 1908: 41). Ehk siis, kunstnikud selle sõna kõige laiemas tähenduses peavad ennekõike looma iseenda, nende biograafiatest peab saama nende endi või teiste eluloojate loomingu osa. Kusjuures oma elulugu teadlikult kujundavate kirjanike, kunstnike, näitlejate jt igapäevane käitumine peab muutuma teatava esteetilise terviku osaks. Eluloome oli ühtlasi osa vene sümbolistide maailma vaimse ümberkujundamise ideest, mille tulemusena pidi kaduma piir elu ja loomingu vahel. Samas on vägagi oluline, et eluloome on võimalik vaid juhul, kui inimene/looja tunnetab oma väärtust. Zara Mintsi sõnul oli eluloome idee vene sümbolistide kõige „ohtlikum idee. [---] Allutada oma käitumine kunsti reeglitele, „mängule”, ilule tähendab eetilisest käitumisest loobumist või vähemalt moraalsete vedrude nõrgendamist. Elu kui kunst ei allunud lisaks ka mõistuse ja loogika seadustele.” (Mints 2004: 398)

Kultuuriloos käsitletakse eluloomet kui kultuurifenomeni, kui erilist kultuurilist tegevust. See on teadlik iseenda elutee struktureerimine, valitud kaanoni realiseerimine oma biograafias (vt lähemalt Bõtškova 2001). Vene kultuuris eksisteerivat eluloomet (või loomingulist biograafiat) kui protsessi hakati teoreetiliselt lahti kirjutama juba 1920. aastate alguses, mil seda ilmingut analüüsisid vene formalistid. Nii näiteks eristas Boriss Tomaševski oma artiklis „Kirjandus ja biograafia” (1923) biograafiaga ${ }^{3}$ ja biograafiata kirjanikke. Esimeste hulka kuuluvad autorid, kes kogu elu vältel täidavad min-

${ }^{1}$ Vt eluloome käsitlust nt Paperno 1994.

${ }^{2}$ Vene kultuuri- ja kirjandusloos on üheselt tunnistatud saksa romantikute rolli mõtestatud eluloomes, luuletajate-romantikute biograafiate sünnis, mille tulemusena tekkis omamoodi nimekiri asjadest ja tegevustest, mis looja pidi oma elus teoks tegema. Samas on selge, et igas kultuuris oli romantikute tee erinev, oma rahvuslikust ajaloost tingitud iseärasustega. Kahjuks ei võimalda artikli maht avada vene hõbeajastu eluloomele eelnenud traditsioonide nüansse, mistõttu soovitame lähemalt tutvuda Deniss Joffe artikliga ja teiste seal viidatud allikatega (vt Joffe 2005).

${ }^{3}$ Juri Tõnjanov on „biograafiaga/elulooga autoreid” nimetanud „kirjanduslikeks isiksusteks" (Tõnjanov 1924: 101-116). 
git kultuuriloolist ülesannet, mille tulemusena kas teadlikult või mitte sünnib nende elulooline müüt, millest paljuski hakkab sõltuma nende loomingu tunnetamine, vastuvõtmine ja selle mõistmine (vt Tomaševski 1923: 8). Need biograafilised legendid on osa kirjaniku elu mõtestamisest ja nende kirjandusteoste vägagi olulisest taustast.

Juri Lotman on kirjutanud, et iga inimene realiseerib oma elulises käitumises mitut valikulist ja üksteisest erinevat programmi, „üks või teine käitumuslik strateegia sõltub suurest hulgast sotsiaalsetest rollidest" ühiskonnas, olgu nendeks siis aadliku, sõjaväelase, mehe, naise, venelase, prantslase või kellegi teise roll (vt Lotman 1994: 332). Tema sõnul hakkas XIX sajandi vene ühiskonna tavaellu üha enam tungima vaatemängulisus, elu muutus teatriks. Eelkõige puudutas see muutus ühiskonna kõrgkihte (vt Lotman 1994: 180-209). XIX sajandi alguse vene kirjanikest on oma eluloome käitumuslikku strateegiat kõige selgesõnalisemalt kirjeldanud aristokraadist luuletaja Konstantin Batjuškov: „Soovin (nimetatagu mu soovi imelikuks!), et luuletajale kirjutataks ette eriline elulaad - pieteetlik dieet. Ühesõnaga, luuletaja elust tehtaks teadus... Selle teaduse esimene seadus peab olema: ela, nagu sa kirjutad, ja kirjuta, nagu sa elad. [---] ...vastasel juhul kõlab see lüüra valesti.” (Batjuškov 1989)

Tomaševski väitel asendus romantismiajastu „elulooga kirjanike” põlvkond XIX sajandi keskpaiku „eluloota kirjanike” põlvkonnaga. Loomulikult oli neil kõigil oma elulugu, mille hulka kuulub ka looming, kirjanduslik tegevus, „ent see on üksikinimese elulugu, mis pakub huvi kultuuriloolastele, kuid mitte kirjandusloolastele”, kuna nende teosed „on sulgunud enesesse. Mitte ükski nende eluloo fakt ei aita tõlgendada nende teoseid ega muuda neid arusaadavamaks." (Tomaševski 1923: 8)

Ka paljude hõbeajastu vene kirjanike, laiemalt literaatide (tõsi, mitte kõigi) jaoks on piir loomingu ja isiksuse vahel kadunud. Nad ise tegelesid selle lõhkumisega ning muutsid oma elu loominguks. Sajandivahetuse uus eluloome idee sai alguse sümbolistidelt ning nakatas hiljem ka teiste ismide esindajad. Luuletaja ja kriitiku Vladislav Hodassevitši sõnul ei soovinud sümbolistid eristada kirjanikku inimesest ega kirjanduslikku biograafiat isiklikust eluloost. Esmapilgul võib tunduda imelikuna, ent tol ajal hinnati „kirjutaja annet” ja „annet elada" peaaegu võrdväärsetena. Nii näiteks võisid unustusehõlma vajuda nii mõnegi luuletaja teosed, ent tema loodud eluloopoeemi tundsid kõik. Ühe sellise näitena nimetab Hodassevitš kunstnikku ja luuletajat Modest Durnovit, kes ei suutnud jätta erilist jälge kunsti- ja kirjanduslukku: „Mõned nõrgad luuletused, mõni tähtsusetu raamatukaas ja -illustratsioon - ja ongi kõik. Ent tema elust, isiksusest loodi legende." (Hodassevitš 1928: 3) Peamiselt on need eluloome tulemusena sündinud biograafilised legendid osa kirjaniku enda elu mõtestamisest, aga ka nende kirjandusteoste olulisest taustast.

Käesoleva artikli eesmärgiks on vaadata, kuivõrd vastab revolutsioonieelsel Venemaal tuntud kirjandus- ja teatrikriitiku Peeter (Pjotr) Pilski ${ }^{4}$ elu toonase ajastu kontekstile, kas ja kuivõrd sõltusid tema eluloomestrateegiad ajaloolistest muudatustest ühiskonnas ja ka tema enda elust peale emigreerumist.

${ }^{4}$ Artiklis on Pjotr Pilski eesnimena kasutatud Päevalehes pruugitud eestipärast varianti - Peeter Pilski. Toona kirjutati tema perenime Pilsky. 
Kuna artikli autori arusaamist mööda on Peeter Pilski üks neist hõbeajastu literaatidest, kes kujundas oma elukäiku teadlikult ehk ajastukohaselt, siis on oluline ära tuua Pilski ainus autobiograafia, mille ta kirjutas 1913. aastal kriitiku ja kirjandusloolase Semjon Vengerovi „Vene kirjanike ja teadlaste kriitilis-biograafilise sõnaraamatu" jaoks.

Minu kodumaa on Orjoli linn. Seal abiellus 144. Kašširi jalaväepolgu ohvitser Mossei Nikolajevitš Pilski krahv Devieri tütre Neonilla Mihhailovnaga. Esiklapsena sellesse perekonda sündisin 16. jaanuaril 1879. aastal mina. Ema sooviks oli väärtustada peres aristokraatlikku train'i, ent isa oli sellele suuresti vastu. Nii imelik, kui see ka ei tundu, olime selle vastu ka meie - lapsed. Mäletan end rohkem tänaval kurni- või kossimängu mängimas kui sõnakuuleliku bonne kasvandikuna.

Lugema õppisin ise, abi sain ka päevnikult ning juba 6-aastaselt teadsin peast kogu Puškinit. See oli esimene mulle kätte sattunud raamat ning esimene autor, kes pani mind luuletusi kordama.

Tõeline õppimine sai alguse 7-aastaselt ning kümnesena läbisin Moskva IV Kadetikorpuse konkursseksami, suisa esimesena, mis on üllatav, kui arvestada seda, et õppida mulle eriti ei meeldinud. Ka korpuses liikusin klassist klassi edukalt edasi. Erilisi tulemusi demonstreerisin kirjanduses ja ajaloos. Muuseas huvitusin ka matemaatikast, kui aga Sõjaväeakadeemias (Aleksandri-nimelises) sain tundma kõrgemat matemaatikat - armusin sellesse.

Mind mõjutanud õpetajatest ei ole ma unustanud C. P. Paltalonet, M. P. Bogolepovit ja N. I. Speranskit. Esimene neist õpetas kirjandust, teine - ajalugu ja kolmas - juriidikat. Teistest meeldivatest mälestustest mainin Valeri Brjussovi ringi, kus me, erinevate koolide õpilased, käisime koos, et rääkida kirjandusest ja selle üle vaielda. Ent erilise tänutundega meenutan professor Nikolai Iljitš Storoženkot, kes veenis mind loobuma sõjaväest ja saama professionaalseks literaadiks.

Ajakirjanduses hakkasin oma tekste üllitama juba kadetikorpuse päevil ning ohvitseriks saamist takistasid kohalikus lehes „Minski Listok” (toim K. I. Zinovjev) ja Kiievi ajalehes „Žizn i Iskusstvo” ilmunud bibliograafilised ja kriitilised kirjutised. Loobudes N. I. Storoženko veenmisel sõjaväeteenistusest, hakkasin kirjutama Moskva „Kurjeri” jaoks, kus avaldasin bibliograafilisi märkmeid, kus ilmus ka mu esimene jutustus „Mis meid ees ootab”, mille kiitis heaks selle lehe toonane kirjandusrubriigi toimetaja L. N. Andrejev. Üsna pea suundusin „Kurjerist” „Birževõje Vedomostisse” ning veel samal, 1902. aastal ilmusid „Mir Božis” kaks minu jutustust: „Vabrikukorstna juures” ja „Sõbrannad". Samas ajakirjas avaldasin veel rea kriitilis-bibliograafilisi kirjutisi ning osa neist koondasin ühise pealkirja „Armee ja ühiskond” alla, ent nende ilmumine jäi pooleli ajakirja sulgemise tõttu. Teistest igakuistest väljaannetest üllitasid mu teoseid: „Russkaja Mõsl”, „Vestnik Znanija”, „Nauka i Žizn”, „Žurnal Dlja Vseh” (toim V. S. Miroljubov), „Pravda” (toim V. A. Koževnikov) jt. Töötasin paljudes ajalehtedes: „Novosti”, „Russkoje Slovo”, „Mõsli” (esseerid, 1906), „Kurjer”, „Birževõje Vedomosti”, „Odesskije Novosti”, „Svobodnaja Mõsl”, „Utro” (Harkov) jt, aga ka paljudes nädalalehtedes ja ajakirjades. Omaette raamatutest on ilmunud: „Jutustused”, „Kriitilised artiklid”, „Soo prob- 
leem, soolised autorid”, „Kaitse ja provokatsioon”, „Härra Petrograd”. Olen paljudele raamatutele kirjutanud eessõnu ja sissejuhatavaid artikleid, neist olulisimaks pean kriitilist artiklit Solovjov-Andrejevitšist, mis juhatas sisse tema Korbasnikovi kirjastuses ilmunud „Kirjandusloo”.

Kõige rohkem tõmbab mind kriitika, mida pean kõige enam rõõmu pakkuvaks loominguks, mõistan seda kui ühe hinge arusaamist teisest, kui kõrgeimat ja kaunimat kunsti, millest olen juba kirjutanud ja saan veelgi kirjutama. (VKI, f 377, n 7, s 2836, 1 1-2)

Pilski autobiograafia täienduseks lisan, et ta osales Vene-Jaapani sõjas ja Esimeses maailmasõjas, kusjuures mõlemas sai ka haavata. Viimases vigastas pommikild väga raskelt tema paremat kätt, mistõttu pidi teda hiljem kirjatöö juures sageli abistama näitlejannast abikaasa Jelena Kuznetsova, kellega Pilski abiellus oma sõnul 1915. aasta novembris.

1918. aasta algul organiseeris Pilski esimese Ülevenemaalise Ajakirjanduskooli, kuhu kutsus esinema paljusid tolleaegseid edukamaid ja olulisemaid ajakirjanikke-praktikuid ja erinevate valdkondade teoreetikuid. ${ }^{5}$

Sama aasta kevadel ilmus ajalehes Petrogradskoje Eho terve rida Pilski vesteid ja artikkel „Hullusärki” (1918, nr 64), kus ta kirjeldas enamlaste liidreid kui hullumaja kandidaate, kes kõik vajavad vastavat ravi ning hullusärki mässimist. Arvestades toonast olukorda, ei pidanud ta kaua ootama arreteerimist. Terve 1918. aasta suve ja sügise hakul istus ta sõjaväevanglas, oodates kohtuotsust. Ent sõjaväetribunali ette ta ei jõudnudki, sest vahepeal oli ta ajakirjanikest kolleegide käendusel ja lubadusega riigist mitte lahkuda vanglast koju lastud. Oma hetkelise vabaduse kasutas Pilski ära asjade kokkupanemiseks ja Petrogradist põgenemiseks. Pilski enda sõnul sai tema põgenikutee alguse 1918. aasta 20. oktoobril.

Moskva - Orjol - Kiiev - Herson - Odessa - Kišinjov - Varssavi jpt väiksemad asulad on kohad, kus Pilski viibis lühemat või pikemat aega oma kolmeaastase põgenikutee jooksul. 1921. aasta 2. oktoobril jõudis ta Riiga, kus mõni päev hiljem sai temast sealse venekeelse ajalehe Segodnja kaastööline ja seda peaaegu kaheks aastakümneks. Pilski ajakirjanduslik töö katkes 1940. aasta mais, kui ta jäi haigevoodisse parema kehapoole halvatuse tõttu. Sama aasta suvel tulid NKVD esindajad teda arreteerima. Pilski korter otsiti läbi ning tema kirjanduslik arhiiv (artiklid, kirjavahetus, päevikud jms) viidi ära, teda ennast, arusaadavatel põhjustel, mitte. Nende sündmuste tõttu halvenes kriitiku seisund veelgi. Pilski suri Saksa okupatsiooni päevil 21. detsembril $1941 .^{6}$

Eksiiliaastate sisse jäävad ka Peeter Pilski viis Eesti-aastat - 1922-1927. Siin elatud aja jooksul tegi ta kaastööd kohalikele vene- ja eestikeelsetele ajalehtedele (Poslednije Izvestija, Naša Gazeta, Vesti Dnja, Päevaleht jt) ja ajakirjadele (Emigrant, Sõdur jt). Ei katkenud tema kaastöö ka Riia ajalehele Segodnja, kus sel perioodil ilmusid eelkõige ülevaated Eesti eluolust, kohaliku vene teatri tegemistest jms. Kuna Pilski oli revolutsioonieelsel ajal jõudnud tutvuda nii mõnegi tulevase Eesti kõrge riigitegelasega (nt Konstantin Päts, Ants Piip jt), siis kaasati teda aeg-ajalt ka teatud riiklikesse tegemistesse, mis vajasid ajakirjanduse kajastust. Nii näiteks oli ta ainsa kohaliku vene

${ }^{5}$ Samasugust kooli üritas Pilski organiseerida 1923. aastal ka Eestis, ent tulutult. Hiljem, 1930. aastatel õnnestus tal ajakirjanduskool käivitada Riias.

${ }^{6}$ Lisaks veel nii palju, et Pilski abikaasa Jelena Kuznetsova põgenes 1944. aastal Riiast Saksamaale, kust ta Eesti kodanikuna sai loa asuda elama USA-sse. 
ajakirjanikuna kaasas Eesti riigipea Jüri Jaaksoni Riia-visiidil 1925. aastal, korduvalt kutsuti teda isiklikult Eesti sõjaväe manöövritele jne. Siinsed viis aktiivset tegevusaastat päädisid 1927. aasta juunis talle Eesti Vabariigi kodakondsuse andmisega. Varsti pärast seda naasis Pilski Riiga, kust ta aeg-ajalt mõne kirjandusürituse, konkursi jms raames ka Eestit väisas.

\section{Kriitik Peeter Pilski eluloome}

Võttes aluseks eluloome idee (elutee teadlik kujundamine, biograafias mingi valitud kaanoni realiseerimine) ja meie teadmised Pilski eluloost, ${ }^{7}$ võime julgelt öelda, et Peeter Pilski oli üks neist vene hõbeajastu kultuuritegelastest, kes nii nagu nt Aleksandr Blok, Andrei Belõi jpt kujundas oma elu vägagi teadlikult, vastavalt kaanonile, mis peitub tema järgmises mõttekäigus: „Selleks et kriitika oleks huvitav, st oleks vajalik, peavad seda kirjutama huvitavad ehk vajalikud, targad ja tähelepanelikud inimesed. Huvi kriitika vastu ja selle tähendus peituvad eranditult kriitiku enda isikus. Kui ta on piiratud ega ole tark, ehkki on väga kohusetundlik ja töökas, pole ta huvitav, mis tähendab - teda pole vaja." (Pilski 1910: 150-151) Kõigele sellele lisab ta, et kriitik peab sarnaselt kunstnikule olema võimeline ümber kehastuma, läbima kunstnikuna kogu oma loomingulise tee ning kokkuvõttes suutma kogetut edasi anda, lahti seletada ja ka lugejale sisendada. „Ühesõnaga, loomingulise kriitika tee kulgeb mööda kunstniku teed” (Pilski 1910: 153). Kokkuvõtvalt: kriitik Pilski kaanon oli olla huvitav ja tark inimene, kes on võimeline elama sarnast elu loojatega, nendega sammu pidama.

Seda, et erudeeritus on Pilski jaoks oluline, nägime juba tema autobiograafias, kus ta muuseas nimetas ka Valeri Brjussovi kirjandusringi. Kaasaegsed tunnistavad, et see ring ei olnud lihtsalt noorte kooskäimise koht, vaid oluline oli oma ideede ja mõtete väljendamine. On kirjutatud ka Pilski tegevusest seal: „Üheks kõige tulihingelisemaks diskuteerijaks oli P. Pilski. Ta tundis väga hästi vene kriitilist kirjandust, oskas esile kutsuda vaidlusi ning seejärel õigeaegselt seljatada oma vastast. Brjussovis leidis ta tugeva vastase, kes oli Pilskiga täiesti vastupidisel arvamusel, aeg-ajalt isegi paradoksaalsetel seisukohtadel, mistõttu kirjanduslik vestlus muutus sageli nendevaheliseks võitlusturniiriks." (Stanjukovitš 1976: 727) Pilski põhjalikke kirjandusalaseid teadmisi mainivad praktiliselt kõik, kes on temast kirjutanud, olgu siis positiivsetes või negatiivsetes mälestustes. Ainus järeldus, mille saame siit teha: Peeter Pilski oli tõepoolest erudeeritud inimene, kes kasutas oma teadmisi kõigi oma tegemiste juures oskuslikult ära.

Lisaks eluloome kaanonile võib Pilski sõnadest välja lugeda ka selle strateegia: isikliku elu peitmine välise alla, selle varjul hoidmine. Eespool toodud autobiograafias mainis ta vanemaid, õpinguid rõhuasetusega oma andekusel

${ }^{7}$ Siinkohal tuleb mainida, et tänaseni ei ole õnnestunud tuvastada ühtki P. Pilski arhiivi, ka mitte NKVD poolt konfiskeeritut. Tõenäoliselt see hävitati. Samuti pole teada, mis sai tema Petrogradi jäänud arhiivist (suure tõenäosusega hävis see oktoobrirevolutsioonile ja Pilski põgenemisele järgnenud aastatel). Pilski biograafiat (nii elu- kui ka kirjandusloolist) on käesoleva artikli autoril tulnud aastate jooksul üles ehitada piskust: kriitiku enda mälestuskildudest, mis on ilmunud eri riikide perioodikas, teiste vene eksiilkirjanike kirjavahetustest, mis on mööda ilma erinevatesse arhiividesse laiali paisatud, juhuslikest arhiivileidudest, kaasaegsete memuaaridest jne. Nende otsingute tulemusena on ilmunud mitmeid artikleid: Meimre [1996a], [1996b], 1997, 2001 jt. 
(õppis ise lugema, teadis väikese poisina peast kogu Puškini luulet, sai kadetikorpusse sisse parimana jne) ja huvidel, samuti ajakirjanduslikku aktiivsust, kuid ei midagi enamat. Oma avalikkusele mõeldud lühiautobiograafia lõpetab ta fraasiga: "Minu isiklik elu ei ole kellegi jaoks huvitav” (VKI, f 377, n 7, s 2836, 1 2).

Eelnevast nähtub, et Peeter Pilski eluloomel oli kaks tegevusstrateegiat: 1) avalikkusele suunatud tegemised, mida ta kujundas vastavalt n-ö kehtivatele reeglitele ja sarnaselt oma ajastu teiste loovinimestega, ning 2) isikliku elu varjul hoidmine, kuna see ei paku tema arvates kellelegi huvi. ${ }^{8}$ Samas on oluline, et ka isiklik, eraeluline, varju jääv pool (mida oli ka võimalik välja mõelda ja tõe pähe esitada) on ajastukohaselt eluloome osa. Nii näiteks seisnes sümbolist Valeri Brjussovi eluloome peamiselt heasse ja halba mitte uskuva saatanliku luuletaja rolli täitmises. Ta lõi pidevalt endast mingeid legende, ka isiklikku elu puudutavaid, muuhulgas mõtles näiteks välja oma kauged viikingitest esivanemad. ${ }^{9}$ Poeet elas oma kaanonile vastavalt: „Nõuame luuletajalt, et ta tooks oma „pühi ohvriande” mitte ainult luuleridade, vaid iga oma elatud tunniga, iga tunde, armastuse, vihkamise, saavutuste ja ka põrumistega. Poeet loogu mitte oma raamatuid, vaid oma elu.” (Brjussov 1905: 29)

\section{Pilski väljapoole suunatud avalik elu}

Avalikus eluloomes valitseb „dramatismi ja teatraalsuse põhimõte, elutekst realiseerub performance'i tasemel kui etendus, lavastus, vaatamisväärsus” (Hansen-Löve 1998: 69). Kõigil toonastel eluloojatel oli oma teatav imago. Pilskist saame rääkida kui ühest küljest mitte kõige meeldivamana kirjeldatud kriitikust, kes veetis väga palju aega erinevates avalikes lõbustusasutustes, mille tulemusena on kaasaegsed tema kohta öelnud, et ta oli „kõrtsi kakukull”, „parim avansside norija”, „targim laenuvõtja” jne. Teisalt on teda peetud erudeeritud, oma valdkonda igapidi hästi tundvaks kirjandus- ja teatrikriitikuks. Kolmanda kuvandina võib nimetada tema n-ö kahe näoga Januse olemust: ühel hetkel ta kiitis sind ja su loomingut taevani, teisel hetkel aga tegi maatasa. Pilski oli kriitik, kelle arvamust ühtaegu oodati ja kardeti, sest kunagi ei saanud olla kindel, millega ta seekord välja tuleb.

Pilskit kui Janust iseloomustab kõige selgemini tema hinnang ja mõju Mihhail Artsõbaševi romaani „Sanin” saatusele. ${ }^{10} 1906$. aastal pöördus Pilski poole ajakirja Mir Boži toimetaja A. Bogdanovitš, kes palus, et kriitik räägiks Artsõbaševiga „Sanini” teemal. Nimelt kolm aastat varem polevat Bogdanovitš lubanud „Saninit” oma ajakirja veergudel avaldada, kuna selle „mõnede stseenide naturalism asetseb pornograafia piiril, mis kõige tähtsam, see on deka-

${ }^{8}$ Antud juhul väärib mainimist see, et eluloome (Pilski puhul avaliku elu kujundamine) aktiivseim periood jääb maailmasõjaeelsesse aega. Ent elulood saadavad loomeinimesi ka edaspidi, ehkki neid enam ei kujundata. Pilski puhul on oluline, et oma eluloome teist osa isiklikku elu - hoiab ta varjus kuni elupäevade lõpuni.

${ }^{9}$ Brjussovi maskide kohta vt Mints 2004: 398-404.

${ }^{10}$ Romaan „Sanin” oli Artsõbaševi loomingus kõige skandaalsem teos, see kutsus esile erinevaid diskussioone, pornograafia süüdistusega kohtuprotsesse jpm. Romaani põhiidee peitub inimese soovis rahuldada oma soove ja vajadusi. Toonane vene ühiskond jagunes kaheks: need, kes toetasid romaani, ja teised, kes olid selle aktiivsed vastased. Romaani aktiivseim lugeja oli noorsugu, kes organiseeris isegi „saninite” ühingu. Teos tõlgiti kiiresti paljudesse keeltesse, nagu saksa, prantsuse, itaalia, taani, bulgaaria jt. 
dentlik, ei vasta hetke poliitilisele meelsusele" (Kuprina-Jordanskaja 1966: 80). Pilski suutis Artsõbaševi ära rääkida ning 1907. aastal ilmus romaan selle ajakirja veergudel. Kuna varem oli Pilski Artsõbaševi teoseid oma arvamustes kiitnud, pöördus viimane omakorda kriitiku poole palvega kirjutada romaani kohta mõni rida. Kriitilise kirjatöö tulemuseks oli kahe kirjamehe suhete jahenemine, seejärel „vaen, esialgu vaikne, hiljem avalik, puhkes sõda ning kui see ei olnud kolmekümneaastane, siis palju aastaid kestnud sõda küll” (Pilski 1927).

Teistlaadi mälestuskillu leiame sümbolist Andrei Belõi memuaaridest: „Vanade ajakirjanike kontingent oli „tore” küll. Ületades enneolematu kergusega kümneid takistusi, olid nad hetkega võimelised eilsetest ässitajatest muutuma meie [sümbolistide $-A$. $M$.] tulihingelisteks kaitsjateks, et kolme päeva pärast jällegi hammustama hakata. P. Pilski kuulutas end korduvalt sümbolistide toetajaks ning, lubades avaldada meie kaitseks kümme vestet, hakkas jälle endist laulu laulma. Muutuste motiiv - kerge kättemaks. Kord oli ta Moskvas läbisõidul ning tuli „Vessõ” toimetusse ning hakkas ilma igasuguse motiveeringuta suurt summat avansiks välja nuruma, saades eitava vastuse - maksis kätte följetoniga.” (Belõi 1990: 232)

Pilski ise pidas selliseid $n-0 ̈$ loomingulisi meelemuutusi vigadeks, mis sageli on tingitud elust enesest või kirjanduse olukorra muutumisest:

Ma pole hetkegi tundnud häbi, kui mul on tulnud tunnistada oma vigu. Pole minutitki kahelnud: kas teatada sellest kõva häälega või vaikida, vaikselt teiste teemadega tegelema hakata ning näidata oma vaatekohtade muutumist pikaajalise ja pideva või kerge ja märkamatu evolutsioonina. Olen suhted endiste sümpaatiatega maha matnud. Ma ei ütle lahti, usun, ei ütle kunagi lahti oma endistest sõnadest, mis on olnud tingitud tolle ajahetke vaadetest. Esteetiline individualism elab minus ka praegu. Mul olid ja on omad isiklikud sümpaatiad ja pettumused. Kui neid karta, siis tuleb õppida kikivarvul käima, tuleb hakata astuma vargsi, kartlikult, kuulmatute sammudega, enam ei tohi usaldada oma maitset, oma mõtteid ega ka sulge. Kriitiku kõige suurem eksimus on otsus elada kogu elu vigu tegemata. (Pilski 1909)

Üheks olulisemaks Peeter Pilski oskuseks pidasid tema kaasaegsed oskust tunda algajate kirjanike ja luuletajate seas ära andekaid, neid, kes jõuavad valitud teel kaugele. Selliseks andeks oli nt tulevane akmeist, luuletaja Nikolai Gumiljov, kelle esimestes kirjatöödes nägi Pilski „head kunstilist maitset ja tõsist esteetilist kasvatust”, esimestes luuletustes aga „kultuursust” (L. F. 1908). Gumiljov ise on tunnistanud, et Pilski oli üks esimesi kriitikuid, kes teda märkas ja kutsus algaja luuletaja tegema kaastööd ajalehele Novaja Russ.

Pilski püüdis noori igat moodi toetada ja aidata. Lisaks nende mingisse väljaandesse tööle kutsumisele korraldas ta neile või ka uute kirjandusvoolude (nt futuristid) kirjandusõhtuid, kus Pilski ise esines sissejuhatavate kõnedega. ${ }^{11}$ Viimaste puhul meenutavad sündmustes osalejad kriitikut hea ja osava sõnameistrina. Sageli mainiti kiitvate hinnangute kõrval seda, et Pilski oli lisaks sõnaosavusele ka meister nendest õhtutest omakasu saama. Nii näiteks meenutab hilisem tuntud nõukogude kirjanik Valentin Katajev,

${ }^{11} \mathrm{Ka}$ Eestis elades esines Pilski sageli kirjandusõhtutel, juhatas sisse seal külalisesinemistega üles astunud näitlejaid, lauljaid jne. 
kuidas Pilski mõtles välja suurepärase mooduse raha teenida. Vahetult enne maailmasõda kutsus ta ajalehekuulutuse kaudu kokku kõik Odessa noored luuletajad, et nende seast välja valida parimad, kellega minna n-ö turneele: „See Pjotr Pilski, sundimatu olekuga osav Odessa följetonist ja kirjandusliku maitse kujundaja... valis välja rühma noori luuletajaid ning vedas meid terve suve mööda meelelahutusaedasid, suvitusteatreid, erinevaid Odessa suvituskohti..., kus me... kandsime igavusest tülpinud suvitajatele ette oma luuletusi. Pilski ise, küüniline, purjus, esines eessõnaga meie loomingust, mõeldes välja uusi pealkirju ning ajades segamini isegi meie nimed. Raha ta meile muidugi ei maksnud, tasus vaid trammikulud ja sedagi mitte alati." (Katajev 1935) Mihhail Zagrebelnõi kirjutas raamatus „Eduard Bagritski”, et odessiitide seas olevat levinud nali: „...sarnaste ettevõtmiste tuludega oli võimalik ära toita vaid kanaarilindu. Ja kuna Pilskist ei saanud majaomanikku ega avanud ta ka arvet Šveitsi pangas, tundub, et see nali vastas tõele. Tõsiselt võetavatena tunduvad ka need pealtnägijad, kelle käest Pilski võttis (tagastamatut) laenu. Tõsi, ta ei ületanud kunagi 25-rublast limiiti. Sellise summa laenanud inimese rahakott oli edaspidi analoogsetest rünnakutest prii." (Zagrebelnõi 2012) Tolle aja noored ise aga ei nurisenud, kuna toonaste reeglite kohaselt oli gümnasistidel keelatud avalikult esineda, ent nende kirjanikutee ristiisa Peeter Pilski kavalus ja oskus erinevatest, kohati keerulistest olukordadest välja tulla andis neile siiski võimaluse tutvustada ennast ja oma loomingut avalikkusele.

\section{Teatraalsus/mängulisus eluloomes}

Eluloome omandab teatud teatraalsuse ehk mängulisuse erinevad elemendid: valitud rollile vastav käitumine, kostüüm, maskid, sh pseudonüümid jne. „Vastavalt eluloome koodeksile pidi kunstniku välimus vastama tema valitud rollile. Siit nii mõnegi kultuuritegelase imelik enesevormistus: noore Jessenini veesaapad ja rahvuslike ääristikanditega särgid on tema talupojarolli atribuudid, „Majakovski kollane kampsun („kõrvakiil avalikkuse maitsemeelele” - tähistas tema luuletajast huligaani rolli). Blok kandis sametjakki, meenutades sellega eelkõige endale, et ta peab vastama Poeedi kõrgele rollile. Gumiljov kandis kõikjal, mitte ainult avalikes kohtades, vaid ka maal puhates, publiku puududes, silindrit ja Pariisi frakki, mis pidid rõhutama „Pariisi dändi”, elegantse esteedi imagot." (Titkova 2011: 296)

Pilski järgib eluloome kontseptsiooni peaaegu tervikuna, mistõttu võib tema elulugu uurides kohata enamikku ajastuomaseid teatraalseid, mängulisi elemente: välimus, käitumine, loominguline suhtlemine, nimi-mask jne. Käitumuslikust ja loomingulise suhtlemisega loodud teatud mõttes mustrist oli eespool juba juttu. Kergesti äratuntav ja meeldejääv välimus oli ka kriitik Pilski jaoks oluline. Kes ja millisena mäletas tema välimust: „Pilski... krimpsutas mustaratsmelise pensneega intelligentselt ohjatud hobusenägu" (Katajev 1935); „silmapaistev noormees... Näpitsprillides. Hoolikalt aetud lõug. Puhas ülikond. Moodne lips... Keigar” (Oršer 1930: 18); „kõhnavõitu, piiratud vuntsidega, iga minuti tagant kohendas vasaku käega oma ninal raamideta näpitsprille, paremaga tegi mingeid oraatorile omaseid liigutusi” (Karpov s. a.); „Nägin ja ei suuda unustada, kuidas ta põlevad silmad läksid pärani, kuidas silmavalged värvusid punaseks ja valgusid pisaraid täis. Mäletan samuti, kuidas üks andekas kriitik [Pilski - A. M.] närviliselt kohendas kahe näpuga oma 
ninal näpitsprille, et varjata niiskeid palgeid” (Kuprin 1931); „Pilski toetub viisakalt lauale, näpitsprillid värisevad ta ninal halvasti varjatud naeru tõttu” (Aleksejev 1922); „Pilskil oli küllaltki veenev välimus: suur pea, tugevad näojooned, mõneti iroonilised silmad, peenike nina, mille peale ta istutas väga osavalt näpitsprillid" (Deitš 1969: 286) jne. Pilski teine, emigratsiooniaegne elu on jätnud märgatavalt vähem tema välimuse kirjeldusi, ent mõne siiski. Eestis elanud ja töötanud vene literaat Jüri Šumakov on kriitikut kirjeldanud nii: „Rühikas, kõvera ninaga, näpitsprillides Pilski rääkis alati rõhutatult kõva häälega" (Šumakov 1992: 19).

Nagu näeme, on üks olulisemaid Pilski välimuslikke atribuute näpitsprillid. Lisaks neile võib kohata veel portfelli, mille vahelt sageli piilus välja saunaviht, ülikonda, mantlit jms. Kõik nimetatud elemendid peaks rõhutama haritust, n-ö puhast tööd tegevat inimest, intelligenti, kes Pilski mingisuguse kahtluseta ka oli.

\section{Nimi-maskid ehk pseudonüümid}

Varjunimesid on läbi aegade kasutatud väga erinevatel põhjustel, olgu need siis poliitilised, sotsiaalsed, ametialased vm. Vene kultuuris kasutasid pseudonüüme algselt artistid, kes varjasid sellega oma päritolu või pärisnime. Sarnane vajadus tuli aeg-ajalt ette ka kirjanike ja luuletajate seas. XX sajandi alguseks sai pseudonüümist eluloomeline vajadus. Ei pääsenud ka Pilski oma igapäevases ajakirjanduslikus töös pseudonüümidest. Tolle aja kirjutamata reegliks oli, et ajakirja või ajalehe ühes konkreetses numbris ei kasutatud üht nimekuju mitmel korral (v.a initsiaalid). Pilski oli aga vägagi aktiivne ajakirjanik, ${ }^{12}$ kes avaldas sageli ühes lehenumbris mitu kirjutist. Eriti paistab selline aktiivsus silma tema Eesti-aastatel, kus nt ajalehe Poslednije Izvestija ühes ja samas numbris võis olla 5-6 Pilski kirjutist, vahel ka rohkem. Loomulik, et kõik kirjatööd pidid olema allkirjastatud eri nimedega: alustades perekonnanimest ja lõpetades initsiaalide ja pseudonüümidega.

Tänaseks on käesoleva artikli autoril onnnestunud kindlaks teha ligikaudu 60 Pilski erinevat „allkirja”. Kusjuures emigratsioonis elatud aastatel omandavad tema jaoks erilise tähenduse tema päritolu märkivad n-ö aadlipseudonüümid, ${ }^{13}$ mida ei kohta revolutsioonieelsetel aastatel. Need on: Gr. Devier, P. Hruštšov, P. Trubnikov, P. Šuiski jmt. ${ }^{14}$ Tänu eespool tsiteeritud autobiograafiale teame, et emaliini pidi oli Pilski seotud krahvide Devieridega, kelle esiisaks oli Portugalist pärit juut Anton De Vierra (hilisem nimekuju Devier), kes jõudis Venemaale Peeter I paažina. Hiljem sai De Vierrast Peterburi esimene politseikindral. Siit siis ka Pilski pseudonüüm Gr. Devier (Krahv Devier) ja sellest tuletatud Gr. Dev. ja Gr. B. Devier. Samuti pole Pilski jaoks juhuslik pseudonüümi valik P. Hruštšov. Pilski ja Hruštšovide seosest saame

${ }^{12}$ Eestis ja Lätis elatud 20 aastaga avaldas Pilski paarikümnes ajalehes ja ajakirjas ligikaudu 3000 eri žanris kirjutist.

${ }^{13}$ Kuna Pilski oli elu lõpuni meelestatud nõukogudevastaselt, võib aadlipseudonüümide kasutus olla seotud just tema poliitiliste vaadetega ja omamoodi nõukogudevastase protestiga. Üritas ju nõukogude võim igati hävitada endist, tsaariaegse ühiskonna kõrgkihti, võrdsustada nõukogude inimesi, sh ka staatuselt. Oluline on siinkohal ka see, et oma „aadellikke” pseudonüüme kasutas Pilski sageli just nõukogudevastaste artiklite allkirjastamisel.

${ }^{14}$ Pilski pseudonüümide kohta vt lähemalt: Meimre 2016. 
teada tema kirjutisest „Meie mammad-preilid” (Pilski 1934), kus ta kirjutas, et tema vanaema oli sündinud Hruštšovana ning abiellunud krahvide Devieride perekonda. Voroneži vaimuliku konsistooriumi kirikuraamatute väljavõttest selgub, et Peeter Pilski ema Neonilla vanemateks olid mõisnik ja kolleegiumiassessor Mihhail Devier ja tema abikaasa Anna, sündinud Hruštšova (Anissimova 2008: 76).

Lisaks juba nimetatud aadellikele pseudonüümidele kasutas Pilski veel ka aliasi P. Trubnikov, P. Stogov, R. Velski. Kõik nimetatud olid Venemaal tuntud aadlisuguvõsad, ent kahjuks ei ole senini õnnestunud leida Pilski ja nende auväärsete perekondade vahelisi seoseid (kui neid üldse on võimalik leida). Ent selline seoste loomine kõrgema seltskonnaga, küll pseudonüümide kaudu, jäi omal ajal silma ka tema eksiilelu kaasaegsetele. Nii jõudis Pilski (jällegi eluloomele kohaselt) Riias elanud vene emigrandist kirjaniku Irina Saburova romaani „Vanalinna laevad”, kus autor kujutas teda endise imposantse aadlikust kriitiku Karavajevina, kelle käitumine aga oli kaugel moraalinormidest.

\section{Pilski inimesena}

Pilski tõelisest loomusest on tema kaasaegsed kirjutanud minimaalselt. Põhjusi selleks võib olla mitu. Esiteks, neid, kes tundsid teda ka isiklikus elus, ei olnud tõenäoliselt eriti palju; teiseks, eraelu järjepidev varjamine ja selle avalikkuse ette mittetoomine oli temast kirjutanud inimeste mõtte- ja väljendusmaailma osa. Inimesi, kes teadsid Peeter Pilskit, oli palju, ent neid, kes teda tõeliselt tundsid, oli vähe. Ajakirjanduses peab materjali avaldamiseks olema mingi põhjus. Kriitik Pilski andis neid põhjusi ridamisi. Temaga polemiseeriti pidevalt, ent kirjanduslik poleemika ei olnud koht, kus kirjeldada tema isikuomadusi. Samas ei andnud Pilski inimesena (tema eraeluline pool) kolleegidele enamasti põhjust kirjeldada teda sõbra või abikaasana ja ehk veel mõnest eraelulisest aspektist. Reeglina annavad selleks põhjuse juubelid. Ent ka siin järgib Pilski kiivalt oma strateegiat: eraelu on eraelu, avalik elu on avalik elu.

Teadaolevalt ei tähistanud Pilski ühtegi ümmargust sünnipäeva. Siinkohal peab mainima seda, et pole kindel, kas tema kolleegid üldse teadsid tema vanust. Sünnipäeva ehk küll, aga tegelikku sünniaastat ilmselt mitte. Viimane oli pikka aega teadmata ka käesolevate ridade autorile. 1990. aastate teise poole Pilski elulugu puudutavad lähteandmed (biograafilised, kirjanduskriitilised, memuaarid jm) sisaldasid vägagi erinevat teavet. Ka ametlikud dokumendid on vastuolulised. Siinkohal mõned näited: Rahvusarhiivis leiduv „Välismaalaste registreerimise leht” (ERA, f 1, n 1, s 8360) väidab Pilski allkirjaga kinnitatult, et 1922. aastal oli ta 41-aastane (täpset sünnikuupäeva kirjas ei ole). Lihtne matemaatiline tehe annab Pilski oletatavaks sünniaastaks 1881. Sama aasta 14. jaanuar on kirjas tema Rumeenia väljasõidudokumendis, mis oli Pilski isikutunnistus kuni 1927. aastani, mil talle anti Eesti Vabariigi kodakondsus. Kodakondsustunnistuselt leiame, et Pilski sündis küll 14. jaanuaril, ent 1880. aastal. Meenutan siinkohal, et Vengerovile kirjutatud autobiograafias on Pilski ise oma sünniajaks märkinud 16. jaanuari 1879. Erinevad kirjandus- ja kultuuriloolased on Pilski sünniaastaks märkinud veel ka 1878 ja 1876. Esimene Peeter Pilski elu ja loomingut uurinud Läti kultuuritegelane Juri Abõzov on kirjutanud koguni, et kriitik sündis 16. aprillil 1879. Toon ära veel ühe daatumi, mis on kirjas Pilski isa Moissei sõjaväelase 
teenistuslehel: 14. jaanuar 1875. Seega saame tema sünniaastate „kõikumise” 1875. aastast kuni 1881. aastani. Lahti kirjutamata kogu pikka ja aeganõudvat protseduuri õige sünniaja väljaselgitamise ${ }^{15}$ võib nüüdseks üsna kindlalt väita, et Peeter Pilski sündis 14. jaanuaril 1875.

Samas tekib loomulik küsimus: miks oli Pilskil vaja erinevatel aegadel ja erinevates dokumentides (passid, registreerimislehed, autobiograafia jne) näidata erinevat vanust. Kahjuks pole õnnestunud sellele tänini loogilist põhjendust leida (vt Meimre 2013). Lähtuvalt õigest sünniajast oleks Pilski saanud 1925. aastal Eestis tähistada oma 50. juubelisünnipäeva, mida aga ei juhtunud.

Ainus teadaolev Pilski juubel oli 1931. aastal, mil ta tähistas oma kirjandustegevuse 30. aastapäeva (ka see on kaheldav ja põhjendamatu: kirjatöid hakkas ta avaldama juba 1890. aastate keskel, esimene jutustus ilmus aga 1902. aastal). Ent tänu sellele juubelile ilmusid ajakirjanduses mõned tema heade kolleegide artiklid, kus muuhulgas on õige pisut avatud ka Pilski kui inimese jooni. Üks sellistest autoritest oli Aleksandr Kuprin. Need kaks kirjameest olid sõbrad, kes tundsid üksteist üsna põhjalikult. Kuprin kirjeldab oma artiklis Pilski loomuse arengut läbi aastate. Artikli esimese kolmandiku lõpetab ta mõttekäiguga, miks Pilskist kui andekast kirjanikust siiski ajakirjanik sai: „...vulkaaniline temperament, kaasasündinud kannatamatus, teadmiste ja materjali üleküllus, vastupandamatu tung ajakirjanduslike väitluste poole, kõige lõpuks - raevukas, sõjakas loomus, kõik need iseloomuomadused iseenesest tõid ta ajalehe juurde, kus temast sai üsna kiiresti terav kriitik, asendamatu följetonist ja keevaline vaidleja." (Kuprin 1931) Seejärel konstateerib Kuprin: „Sõda taltsutas, rahustas Pilski raevuka ande maha, samal ajal ka lihvis tema kirjanikuannet" (Kuprin 1931). Oma artikli lõpetab Kuprin emigratsiooniaegse Pilski kirjeldusega: „Aastad, raske kogemus ja eluline mõttetarkus on tema Sevilla temperamendi maha rahustanud. Endisest Pilskist on saanud sügav ja heasüdamlik kriitik. Tema fenomenaalne mälu on salvestanud ääretu hulga nägusid, sündmusi, anekdoote, kõnesid, sõnu ja seiklusi meie endisaegsest Moskva ja Peterburi elust. Tema jutud möödanikust on värvikad ja alati meeldivad." (Kuprin 1931)

Nii sõda kui ka elukoha ja olustiku muutus - eksiiltegelikkus - muutsid Pilskit mitte ainult inimesena, vaid rahustasid maha ka „kahe näoga Januse”. Eestis kirjutas ta: „Kui me siin, eksiilis, ei toeta oma Vene draamateatrit, kaevame me iseendile haua. Kõik meie õigused võidule ja kogu tulevik on koondunud ühte sõnasse: KULTUUR." (Pilski 1922) Siin on kõne all küll teater, ent see väide kehtis ka eksiilkirjanduse ja -kultuuri kohta. Negatiivset võib Pilski kriitikas nüüdsest kohata vaid nõukogude kirjanduse kohta ja ka seal mitte alati.

Ehkki saatus viis peale oktoobrirevolutsiooni kahe sõbra, Pilski ja Kuprini, teed lahku, üritasid nad kontakti hoida. ${ }^{16}$ Kuprin iseloomustas ühes oma kirjas Pilskit järgmiselt: „Ta on tore mees ja minu hea, lahke, vana, lõbus sõber. Ah, kuidas me noortena lõbutsesime. Jõime ja müstifitseerisime inimesi, sikutasime kitse sabast ja nägime nii lõbusat kui ka kurba, käisime kohut ja istusime kinni, suplesime Mustas meres, armastasime ja vihkasime. Kirev

${ }^{15}$ Oluline on siinkohal, et ka Venemaa uurijatel, kelle poole olen pöördunud, pole õnnestunud leida ei Pilski sünnimeetrikat ega ka tema sõjaväelase teenistuslehte, kus eeldatavalt peaks olema kirjas tegelik sünniaeg.

${ }^{16}$ Kahjuks pole nende kirjavahetus säilinud, Pilski oma juba seletatud põhjusel. Kuprini oma on osaliselt hävinud seoses tema kodumaale naasmisega 1938. aastal. Säilinud osas ei ole Pilski kirju. 
oli kõik." (Kaera 1987: 42) Kuna toonane postiühendus ei olnud kõige parem, siis on Kuprini ja Vladimir Guštšiku ${ }^{17}$ kirjavahetuses sageli juttu kaduma läinud kirjadest ja nende uuesti kirjutamisest, aga ka tuttavate aadresside küsimisest. Nii näiteks palub Kuprin korduvalt Guštšikut, et too saadaks talle „püsimatu” Pilski aadressi. Samas on selge, et Pilski aadressi puudumine on lisaks mitte väga korrektsele postiteenusele tingitud ka tema loomusest. Naljaga pooleks kirjutab Kuprin järjekordses kirjas: „Saatke mulle palun Pilski aadress. Ta pole üldsegi Pjotr Pilski. See on tema pseudonüüm. Tema tõeline nimi ja tiitel on Van Peter Pilver, „Lendava hollandlase” kipper. Just seetõttu pole tal pidevat aadressi, ta on saatuse poolt mõistetud igavesele rändamisele." (Kaera 1987: 44)

Teatud mõttes oli Pilski tõepoolest rändur, seda ka Eestis elades, kus tal puudus püsiv aadress. Riigiarhiivis säilinud Pilskiga seotud dokumendid võimaldavad kokku lugeda 16 erinevat elukohta: esimene neist hotell Kuld Lõvi, viimane - Kordese (praegu Kevade) 7-1. Ja seda kõike vaid viie aasta jooksul. On teada, et revolutsioonieelsetel aastatel elas ja töötas Pilski lisaks pealinnale Peterburile veel ka Moskvas, Bakuus, Odessas, Kiievis, Harkovis jm.

Rändaja loomuga Pilskit meenutas tema 15. surma-aastapäeval vene esimese emigratsioonilaine ${ }^{18}$ kirjanik Mark Slonim: „Tal oli püsimatu, ränduri iseloom, ta ei suutnud kaua ühe koha peal paigal olla. Pilski vahetas pidevalt linnu ja väljaandeid... ${ }^{19} \mathrm{Ja}$ millise hoomamatu hulga muljeid kogus ta paljude ränduriaastate jooksul! Talle meeldis enda kohta öelda: Olen elutark ja kogemus mul enneolematu." (Slonim 1956) Slonim mäletas ka seda, et Pilski oli särav ajakirjanik ja „pehme, hea, sentimentaalne ja kaastundlik inimene” (Slonim 1956). Pilski iseloomu pehmust meenutab 1931. aastal ka Pariisis elav vene kirjanduskriitik Aleksandr Amfiteatrov, kes mainib sedagi, et Pilski oli elurõõmus inimene (Amfiteatrov 1931).

Oma isikliku elu varjamise ja selle teiste jaoks tähtsusetuks tegemise võtab Pilski ise väga hästi kokku 1920. aastate lõpus, kui tal paluti kirjutada Riias ilmuma hakkava ajakirja Grimassõ kisti i pera jaoks autobiograafia. Tellitud eluloo asemel kirjutas Pilski:

Mitte kellelgi pole kombeks jalutada ringi alasti. Erandiks vaid Aadam ja kaunitarid. Avameelseid autobiograafiaid pole olemas. Tundes inimesi, peaks nende küsimustele vastama nii:

- Kuidas elate?

- Pole teie asi!

- Kuidas läheb?

- See ei puutu kellessegi!

See pole ülbus. See on lihtsalt loogiline. (Pilski [1928]: 258)

${ }^{17}$ Vladimir Guštšik (1892-1947) - sõdadevahelisel ajal Eestis elanud vene emigrandist proosakirjanik, kelle loomingut tunti ka väljaspool Eestit. Kuna NKVD arreteeris kirjaniku 1941. aasta jaanuaris ja tema elupäevad lõppesid Gorki oblasti vangilaagris, siis on üsna loogiline, et ka tema looming kuulus n-ö kustutamisele ning kõik tema nii Eestis kui ka väljaspool ilmunud teosed suleti erifondidesse või hävitati. Tema kohta vt: Issakov 1996.

${ }^{18}$ Vt vene esimese laine emigratsioonist lähemalt Belobrovtseva, Meimre 2015.

${ }^{19}$ Aastatega paljudest allikatest kogutud andmete kohaselt on Pilski materjalid ilmunud rohkem kui poolesajas perioodilises väljaandes Venemaal, Eestis, Lätis, Bessaraabias, Ukrainas, Prantsusmaal, Ungaris, USA-s jm. 
Võimalik, et kriitik Pilski väljapoole suunatud avalik kuvand osutus niivõrd mõjuvõimsaks, et enamik tema kaasaegseist ei näinudki enam tema tõelist mina. Omaenese mina peitmine või siis selle avamine pelgalt kodus nelja seina vahel võis eluloojatel lõppeda sellega, et tõeline mina kaduski maski taha ära. Nii võis osaliselt juhtuda ka Pilskiga.

Loomulikult oli ka ajal ja oludel oma roll Pilski kui inimese arengus, ent me ei tohi unustada seda, et maailmasõja algusega hakkas vaikselt kaduma ajastuomane eluloome ning paljud ajaga kaasas käinud loomeinimesed hakkasid oma rollidest välja tulema. Seda teeb ka Pilski, ehkki vastavalt oludele ja vajadusele tõmbab ta uuesti maski ette. Tõsi, see mask on muutunud. Endisest ettearvamatu reaktsiooniga kriitikust saab eksiilis omade jaoks reeglina positiivne kriitik, kes praktiliselt igas artiklis läheb ajas tagasi, hoides seeläbi elavana mälestust revolutsioonieelsetest aegadest. Samas ei halasta ta võõrastele - nõukogude kirjanikele, eriti neile, kes pärast oktoobrirevolutsiooni valisid enamlaste leeri ning muutusid seeläbi omadest võõrasteks. Pagulusaastatel ootasid omad pikisilmi Pilski arvustusi, võõrad tõenäoliselt mitte.

Artikkel on valminud Euroopa Liidu Euroopa Regionaalarengu Fondi (CEES Eesti-uuringute Tippkeskus) ja projekti IUT18-4 „Eesti Ida ja Lääne vahel: „oma”, „teise”, „võorra”, „vaenlase” kujundite paradigma XX sajandi Eesti kultuurides” toetusel.

\section{Arhiiviallikad}

Rahvusarhiiv, ERA, f 1, n 1, s 8360.

VKI = Venemaa TA Vene Kirjanduse Instituut (Puškini Maja) = ИРЛИ (Институт русской литературы (Пушкинский дом) Российской Академии наук, f 377, n 7, s 2836, $11-2$.

\section{Kirjandus}

Aleksejev 1922 = Глеб Алексеев, Живые встречи (Иван Бунин). - Фонарь. http:// lanterne.ru/zhivyie-vstrechi-ivan-bunin.html (25. VII 2017).

Amfiteatrov 1931 = Александр Амфитеатров, Рыцарь художественной критики. (К 30-летию литературной деятельности Петра Пильского). - Сегодня, nr 108, 19. IV. An is s i m ov a 2008 = Ирина Анисимова, Писатель Петр Пильский - происхождение и родственное окружение. - Генеалогический вестник, $\mathrm{nr} 33$, lk 73-78.

B atjušk ov 1989 = Константин Батюшков, Нечто о поэте и поэзии. - К. Батюшков, Сочинения в двух томах. T. 1. Москва: Художественная литература. http://az.lib.ru/b/ batjushkow_k_n/text_0010.shtml (11. XII 2016).

Belobrovtseva, Irina, Meimre, Aurika 2015. Sõdadevaheline vene emigratsioon suures ilmas ja väikeses Eestis. - Methis, nr 15, lk 28-46.

B elõ i 1908 = Андрей Белый, Символизм. - Весы, nr 12, lk 36-41.

Belõi 1990 = Андрей Белый, Между двух революций. Москва: Художественная литература.

B rju s s ov 1905 = Валерий Брюсов, Священная жертва. - Весы, nr 1, lk 23-29.

Bõt š k ov a 2001 = Екатерина Бычкова, Жизнетворчество как феномен культуры декаданса на рубеже XIX-XX веков. Диссертация ... кандидата культурол. наук. Москва. 
http://www.disszakaz.com/catalog/zhiznetvorchestvo_kak_fenomen_kulturi_ dekadansa_na_rubezhe_xix_xx_vekov.html (9. XII 2016).

Deitš 1969 = Александр Дейч, День нынешний и день минувший. Москва: Советский писатель.

Hansen-Löve 1998 = Оге Хансен-Лёве, Концепции „жизнетворчества” в русском символизме начала века. - Блоковский сборник, nr XIV, lk 57-85.

Hod a s s evitš 1928 = Владислав Ходасевич, Конец Ренаты. - Возрождение, nr 1045, 12 IV.

I s s a k ov 1996 = Сергей Исаков, Жизнь и творчество В. Е. Гущика. - С. Исаков, Русские в Эстонии. 1918-1940. Историко-культурные очерки. Тарту: Компу, lk 239-254.

Joffe 2005 = Денис Иоффе, Жизнетворчество русского модернизма sub specie semioticae. Историографические заметки к вопросу типологической реконструкции системы жизнь - текст. - Критика и семиотика, nr 8, lk 126-179.

Ka e r a 1987 = Ресси Каэра, Неизвестные письма А. И. Куприна из Парижа в Таллинн. - Радуга, nr 6, lk 40-45.

$\mathrm{Karpov} s$. $a$. = Николай Карпов, В литературном болоте. - Литературное наследие. http://www.nasledie-rus.ru/red_port/001204.php (25. VII 2017).

Katajev 1935 = Валентин Катаев, Встреча. - Красная новь, nr 12. http://ruslit. traumlibrary.net/book/kataev-ss09-01/kataev-ss09-01.html\#comm002034 (11. XII 2016).

Kuprin 1931 = Александр Куприн, Петр Пильский. Тридцать лет литературной деятельности. - Сегодня, nr 108, 19. IV.

Kuprina-Jordanskaja 1966 = Мария Куприна-Иорданская, Годы молодости. Москва: Художественная литература.

L. F. 1908 = Л. Ф., Н. Гумилев. Романтические цветы. - Образование, nr 7, lk 78.

L otman 1994 = Юрий Лотман, Беседы о русской культуре. Быт и традиции русского дворянства (XVIII - начало XIX века). Санкт-Петербург: Искусство-СПб.

M e i m r e 1996a = Аурика Меймре, П. Пильский в Эстонии: 1922-1927. - Балтийский архив. Русская культура в Прибалтике. 1. Таллинн: Авенариус, lk 202-217.

M e i m r e 1996b = Аурика Меймре, Пять сезонов Таллиннского русского театра глазами одного критика. - Балтийский архив. Русская культура в Прибалтике. 2. Таллинн: Авенариус, lk 119-126.

Meimre 1997 = Аурика Меймре, Общественно-литературная деятельность Пильского П. М. в Эстонии в 1920-е годы. - YSTM'96. International Scientific Congress of Students and Young Researches „Youth and Science - Looking into the Third Millennium". Сборник трудов. 2. Москва: Наука, lk 111-113.

Meimre 2001 = Аурика Меймре, Русские литераторы-эмигранты в Эстонии 19181940. На материале периодической печати. Tallinn: TPÜ kirjastus, lk 98-110.

M eim re 2013 = Аурика Меймре, Проблема датировки: биографии деятелей русской культуры в межвоенной Эстонии: к постановке проблемы. - „Радость ждет сокровенного слова...” Сборник научных статей в честь проф. Латвийского университета Л. В. Спроге. Rīga: Latvijas Universitate, lk 158-163.

M e i m r e 2016 = Аурика Меймре, „Простачок”, „Е. Сергеев”, „Наблюдатель”, „Питирим Моисеев" - они же Петр Моисеевич Пильский. - Псевдонимы русского зарубежья: Материалы и исследования. Москва: Новое литературное обозрение, lk 207-218.

M in t s 2004 = Зара Минц, Поэтика русского символизма. Санкт-Петербург: ИскусствоСПб.

O r š e r 1930 = Старый журналист [Иосиф Оршер], Литературный путь дореволюционного журналиста. Москва-Ленинград: Государственное издательство. 
Pa per n o, Irina 1994. Creating Life: The Aesthetic Utopia of Russian Modernism. Toim Irina Paperno, Joan Delaney Grossmann. Stanford: Stanford University Press.

Pilski 1909 = Петр Пильский, Проблема пола, половые авторы и половой год. СанктПетербург: Освобождение, lk 147-148.

Pilski 1910 = Петр Пильский, Критические статьи. Санкт-Петербург: Прогресс, lk 143-167

Pilski 1922 = Петр Пильский, Рецензия о публике. - Последние известия, nr 238, 14. X.

Pilski 1927 = Петр Пильский, М. П. Арцыбашев. - Сегодня, nr 51, 4. III.

Pilski [1928] = Петр Пильский, Петр Пильский о себе. - Гримасы кисти и пера. Сборник русских юмористов-писателей и художников. Рига: Литература, $1 \mathrm{k} 258$.

Pilski 1934 = Петр Пильский, Наши бабушки-барышни. - Сегодня, nr 83, 24. III.

Slon i m 1956 = Марк Слоним, Петр Пильский. (К 15-летию со дня смерти). - Новое русское слово 10 . II.

Stanjukoviť̌ 1976 = Владимир Станюкович, Воспоминание о В. Я. Брюсове. Литературное наследство. Т. 85. Валерий Брюсов. Москва: Наука, lk 713-758.

Šumakov 1992 = Юрий Шумаков, Пристать бы мне к родному берегу... Игорь Северянин и его окружение в Эстонии. Таллин.

Zagrebelnõi 2012 = Михаил Загребельный, Эдуард Багрицкий. Москва. http://lib. rin.ru/book/eduard-bagrickij_m-p-zagrebelnyj/text/ (1. XII 2016).

T i t k ov a 2011 = Наталья Титкова, Театрализация как форма жизнетворчества в русской литературе Серебряного века. - Мир науки, культуры, образования, nr 5, lk 295-297.

Tomaševski 1923 = Борис Томашевский, Литература и биография. - Книга и революция, $\mathrm{nr} 4$ (28), lk 6-9.

Tõ nj a n ov 1924 = Юрий Тынянов, Литературный факт. - Леф, nr 2, lk 101-116.

\section{Peter Pilsky's life-creation strategies}

Keywords: life-creation, Russian Silver Age, pseudonyms, Peter Pilsky

The article deals with the problem of life-creation (zhiznetvorchestvo) on the example of Peter Pilsky's biography. Life-creation was one of the most significant phenomena of the Russian Silver Age, where being an artist meant absolutely no separation between the person and the author (tvorets 'creator') in him, i.e. between one's personal and artistic lives. The article shows how the literary and theatre critic Peter Pilsky formed his „external” biography according to the requirements of the time. In conformity with the credo of life-creation Pilsky pursued his own aesthetic canon: to be an educated and interesting man, who is able to live the same kind of life as the artists, writers and others. At the same time Pilsky had his own life-creative strategy: to hide his private life from the public. The article shows how he managed to implement his aesthetic canon and strategy in his biography throughout the pre-revolution period as well as in exile (in Estonia and Latvia).

Aurika Meimre (b. 1969), PhD, Tallinn University, School of Humanities, Associate Professor of Russian Culture in Estonia, aurika.meimre@tlu.ee 